\title{
The Paradox of Partisanship
}

\section{Meira Levinson \& Ellis Reid (Harvard University)}

\begin{abstract}
:
It is a truism that public school teachers should not take partisan stands in the classroom in ways that discourage students from considering or adopting alternative reasonable perspectives. At least three arguments support this widespread belief.
\end{abstract}

It is a truism that public school teachers should not take partisan stands in the classroom in ways that discourage students from considering or adopting alternative reasonable perspectives. At least three arguments support this widespread belief.

First, public school teachers are public servants; they are employed by, and are expected to serve, the public. Insofar as members of the public embrace conflicting political or ideological perspectives about contentious issues, public servants should not privilege one perspective above others.

Second, a teacher who elevates one partisan position over free inquiry risks indoctrinating, rather than educating, his students. What makes a position politically partisan is precisely that it represents a perspective that is contested by publicly recognized and putatively legitimate and reasonable political groups. But if a teacher takes a partisan stand such that students are discouraged from considering or adopting alternative perspectives, then by definition the teacher is taking a stand on a contested issue in such a way as to impede his students' capacities to engage with reasonable alternative viewpoints. This would seem to match the definition of indoctrination. ${ }^{1}$

Third, teachers who take partisan stands risk using their power inappropriately to dominate vulnerable others. They most directly dominate children, of course, by restricting their access to reasonable alternative perspectives and/or restricting students' expression of their own potentially dissenting views. But partisan early grades teachers may also wield inappropriate power against parents, disrupting parent-child bonds by teaching children that their parents' values or beliefs are wrong. Partisan teachers may similarly interfere with parents' rights (if they exist) to guide their children's moral and political development.

In sum, at least three classes of reasons - (1) the obligations of public servants in general to represent a diverse public; (2) the obligations of teachers in particular to educate rather than indoctrinate; and (3) teachers' duties not to abuse their power over parents and students - support the claim that public school teachers should not take partisan stands in the classroom in ways that discourage students from considering or adopting alternative reasonable perspectives.

At the same time, however, teachers are rightly expected to teach moral and civic norms that are broadly shared across ideological and political lines - especially those that serve as the foundation for shared civic life. In the United States, for instance, public school teachers are appropriately expected to teach students to embrace core civic values such as constitutional democracy and civic equality. In important respects, the promotion of these norms constitutes one of the essential roles of schooling in a liberal democracy.

This is not to say that teachers should necessarily teach uncontested beliefs in a dogmatic fashion. There may be good pedagogical reasons for teachers to adopt a spirit of inquiry even about some matters about which there is no reasonable contestation, whether to model scientific or humanistic inquiry or to deepen students' own reasonable convictions. But we do not expect that students will be encouraged to adopt unreasonable perspectives - and we would be upset if they did. ${ }^{2}$

So far, so good. The bright line between non-directive teaching on partisan issues and directive teaching of foundational civic principles and values dims, however, when the meaning and expression of these latter norms themselves are contested along partisan lines. ${ }^{3}$ The line breaks down even further when these norms are subject to fast shifts in interpretation by one ideological, geographic, or generational community while remaining fixed elsewhere. Fast norm-shifting may occur in response to:

- $\quad$ significant legislation or judicial decisions;

- compelling new scientific or social science evidence;

- $\quad$ large-scale events or phenomena that people feel create a rupture with past understandings or beliefs (e.g. the 9/11 attacks in the U.S., an influx of 
refugees in contemporary Europe, or gun-control activism by students following a mass shooting);

- powerful cultural productions or moments (e.g. beloved Olympic medalists coming out as transgender, the \#metoo movement); or

- $\quad$ sudden shifts by elites that change or even reverse long-standing practices or values, or that shift one party in a way that changes partisan meanings (such as Trump is doing today, and as many conservatives argued that Obama did when he ordered the executive branch to cease enforcing the Defense of Marriage Act and to give protections to undocumented residents through Deferred Action for Childhood Arrivals [DACA]).

Fast norm shifts can be especially challenging to teachers who aspire to be non-partisan because how one appropriately interprets these changes is itself contested, and often partisan. When a civic norm changes quickly, for example, is that a sign that long-standing wrongs have finally been righted, or that fundamental values are being inappropriately diminished?

Many liberals, for example, treat Obergefell, the Supreme Court case that legalized same-sex marriage nationwide, as dispositive about the question of same-sex marriage. The fact that the Court found same-sex marriage bans to be unconstitutional is sufficient for many liberals to declare same-sex marriage a fundamental expression of civic equality. These same liberals, however, are unlikely to offer Citizens United the same deference. The fact that the Court ruled that corporations are persons with respect to speech rights, and that money must be viewed as a form of speech, is something that has liberals up in arms. They fight to overturn Citizens United, and treat corporate personhood as an entirely open question, not settled at all.

Many conservatives, by contrast, take the opposite positions, treating Obergefell as a catastrophic violation of long-standing moral and civic norms in favour of both the 'traditional family' and religious freedom, and treating Citizens United as a long-overdue affirmation of civic equality as realized through political speech rights. Teachers thus find themselves in a bind when trying to teach even basic civic and democratic values. A teacher's decision to treat a Supreme Court decision as the law of the land' versus as still open to contestation itself becomes a partisan decision - or at least be perceived as such by those who disagree with the teacher's choice. This is also true for other presumptively dispositive phenomena such as signed legislation, treaties, and acts of war.

As attitudes about same-sex marriage or GLBTQ+ participation in the military have shifted within the United States, teachers who a decade ago may have treated these topics as reasonably contested or "open" now find themselves expected (and/or expect themselves) to teach these topics as "settled" (Hess \& McAvoy, 2014). ${ }^{4}$ On the flip side, long-standing U.S. civic ideals such as the value of family unification are currently being challenged by President Trump and many Republican members of Congress. Whereas even just a few years ago many public school teachers would have felt on firm ground teaching that the United States values family reunification for both natural-born and naturalized citizens, in 2018 they may fear that such teaching is partisan in light of Republican critiques of 'chain migration'.

Teachers are particularly at risk of being sanctioned for taking partisan stands when they violate local understandings of civic norms. While both Rochester and Seattle Public Schools have sponsored district-wide initiatives in support of Black Lives Matter, for example, districts in more conservative areas have fired teachers for simply wearing a \#BLM button. ${ }^{5}$ Similarly, in Mt. Pleasant, Michigan, fifth-grade teacher Mika Yamamoto was fired after Election Day 2016 for saying that she felt unsafe "because our country had just elected a president who had openly spoken out against women, people of colour, the LGBTQ+ community, and other people he felt were different than him." 6 The school principal, Yamamoto alleged in a lawsuit filed after her termination, told her that "the community [was] not ready for [her] voice" and that her views would be better suited for a big city like New York or Chicago. ${ }^{7}$ The principal's claim was likely accurate, as many urban districts issued statements following the election that explicitly committed to combatting hate and bigotry. But it does little to clarify whether Yamamoto's similarly factually accurate statement (she was feeling scared, and President-elect Trump had openly spoken out against the groups she named) should be treated as inappropriate partisanship when spoken in a more conservative political context.

Teachers who strive to teach in a non-partisan fashion, therefore, are faced with a complex set of factors in deciding when to treat an issue as open versus settled, and how to distinguish between the two. Diana Hess helpfully names this challenge as one of teaching "in the tip" (Hess, 2009). When a controversial issue is 'in the tip', it is moving from being widely viewed as open to being widely viewed as settled (or vice versa) - but people disagree about whether it is in fact open or settled. In other words, some people view the issue as still being reasonably contested, say, while others view it as being settled in a way that no reasonable person would support the other side. Teaching in the tip is particularly challenging because there are two separate levels of contestation: one over the substance of the controversy, and a separate one over whether the issue should be treated as reasonably contestable at all.

While these challenges bedevil teachers from across the political spectrum, they are heightened for those who stand in opposition to the direction (even tidal wave) of change. 
At this political moment, therefore, we are particularly concerned about how teachers navigate 'the tip' created by President Trump's breathtakingly fast challenges to fundamental civic norms opposing ethnoracial and religious discrimination, celebrating diversity, supporting a free press, protecting judicial and prosecutorial independence, and protecting bodily integrity with respect to sexual assault and police brutality (among many others).

Trump has accomplished two things in an astonishingly short period of time. First, he has normalized normative claims and language among a wide swath of the American public that over the past few decades had been uniformly and publicly disavowed (even if they had persisted in private). Second, he has brought most of the Republican Party with him, so that political elites are also divided around civic norms that had been collectively embraced just 24 or 36 months ago. Teachers who are committed to non-partisan but civically-engaged teaching thus find themselves uncomfortably asking themselves whether they must now treat as open and legitimately contested a wide variety of fundamental civic values that they and most Americans have long treated as settled. Is it appropriate to teach that many of President Trump's statements and actions are not just unprecedented, but also wrong?

Hess and McAvoy again offer the most useful way for teachers to assess how and whether to treat an issue as controversial, but even they falter in the face of normative rupture. They argue that teachers should rely on the "politically authentic criterion" to decide whether to treat complex normative and policy issues as open (Hess \& McAvoy, 2014). According to this criterion, teachers should treat issues as controversial "when they have traction in the public sphere, appearing on ballots, in courts, within political platforms, in legislative chambers, and as part of political movements" (Hess \& McAvoy, 2014, pp. 168-169). As legislators propose arming teachers, major parties adopt platform planks that state that "Homosexuality is a chosen behaviour that is contrary to the fundamental unchanging truths that has been ordained by God in the Bible...," 8 white supremacists march in the thousands in Charlottesville, and the President of the United States celebrates murderous autocrats such as Duterte and Putin, however, we believe that the politically authentic criterion offers insufficient normative guidance for teachers who are frankly concerned about the death of democratic norms and institutions. ${ }^{9}$
We hence find ourselves confronted by a serious philosophical and practical challenge. As teachers navigate both how (and whether) to teach fundamental civic values such as democratic constitutionalism and civic equality, and how (and whether) to respond to fast norm-shifting around these beliefs, they will inevitably find themselves taking partisan stands. No single criterion or even group of criteria can guarantee that teachers either stand on firm ground or must give way when they defend long-held foundational civic norms against legislative, executive, or judicial attack, powerful cultural moments, elite shifts, or other normative ruptures. Given this, we conclude that teachers cannot avoid taking partisan stands in the classroom precisely because there is no truly non-partisan standard for setting boundaries around what should count as a reasonable. At the same time, however, we continue to affirm the arguments with which we opened this essay: that public school teachers should avoid taking partisan stands in the classroom in ways that discourage students from considering or adopting alternative reasonable perspectives.

How, then, should we move forward? Some important recommendations have already been made. Hess and McAvoy have argued persuasively for the importance of teachers working collaboratively to help ensure a wide range of contested views are well represented (Hess \& McAvoy, 2014). Philosopher Emily Robertson has argued that teachers who engage students in discussions over reasonably contested issues ought to be accorded some sort of due process protections to help ensure teachers who run afoul of community norms aren't summarily dismissed (Zimmermann \& Robertson, 2017).

We believe more work needs to be done, though, to help develop new insights about what norms should guide teachers 'in the tip'. We caution that these norms must themselves be applicable across partisan lines. In other words, they should apply not only to liberals teaching in the tip under President Trump in Mt. Pleasant, Michigan, but also to conservatives teaching in the tip under President Obama in Seattle, Washington. As our argument admittedly suggests, normative interpretation unshaded by partisanship is itself an elusive, perhaps impossible, goal. There may therefore be no path out of this morass. But we hope to be proved wrong, as public school teachers are an essential bulwark of democratic education in these (and many other) trying times.

\section{References}

Hand, M. (2017). A theory of moral education. Routledge.

Hess, D. E. (2009). Controversy in the classroom: The democratic power of discussion. Routledge.

Hess, D. E., \& McAvoy, P. (2014). The political classroom. Routledge. 
Taylor, R. M. (2017). Indoctrination and social context: A system-based approach to identifying the threat of indoctrination and the responsibilities of educators. Journal of Philosophy of Education, 51(1), 38-58.

https://doi.org/10.1111/1467-9752.12180

Zimmerman, J., \& Robertson, E. (2017). The case for contention: Teaching controversial issues in American schools. The University of Chicago Press.

\title{
Recommended Citation
}

Levinson, M., \& Reid, E. (2018). The paradox of partisanship. On Education. Journal for Research and Debate, 1(1). https://doi.org/10.17899/on_ed.2018.1.3

\begin{abstract}
About the Author
Meira Levinson is Professor of Education at Harvard Graduate School of Education. Her books include No Citizen Left Behind, Making Civics Count (co-edited with David Campbell and Frederick Hess), and Dilemmas of Educational Ethics (co-edited with Jacob Fay).
\end{abstract}

Ellis Reid is a doctoral student at Harvard Graduate School of Education.

\footnotetext{
${ }^{1}$ See Taylor (2017) for an excellent discussion of the current state of philosophical scholarship on indoctrination.

${ }^{2}$ When teachers in Houston recently assigned students to assess arguments both for and against slavery, for example, they were rightly excoriated for seeming to suggest that the value of slavery was an open question. See ' 3 good reasons for slavery' homework assignment sparks controversy (n.d.). Retrieved March 6, 2018 from Click2Houston website, https://www.click2houston.com/news/national/-3-good-reasons-for-slavery-homework-assignmentsparks-controversy. For a discussion of related controversies that have arisen in North Carolina, Wisconsin, California, Georgia, and New Jersey: Anderson, M. (2018, February 1). What kids are really learning about slavery. The Atlantic. Retrieved from: https:/www.theatlantic.com/education/archive/2018/02/what-kids-are-really-learning-about-slavery/552098/

${ }^{3}$ See Hand (2017) for a discussion of directive versus non-directive teaching.

${ }^{4}$ Hess \& McAvoy (2014) expand on the concept of open versus settled issues in an incredibly clear and lucid way.

${ }^{5}$ Mays, M. (2016, December 3). A Teacher Wore a Black Lives Matter Pin to Class. Now, He Is Banned from School. Miami

Herald. Retrieved from: http://www.miamiherald.com/news/nation-world/national/article118686918.html.

6 Maynard, M. (2017, February 12). Interview with Mika Yamamoto. Mark Maynard. Retrieved from: http://markmaynard.com/2017/02/5th-grade-charterschool-teacher-mika-yamamoto-fired-from-michigans-renaissance-public-school-academy-where-she-was-the-only-teacher-of-color-claims-she-was-toldby-her-principal-the-community/

${ }^{7}$ Ibid.

${ }^{8}$ Permanent Committee on Platform and Resolutions. (2016). Republican Party of Texas. 2016 State Convention of the Republican Party of Texas. Retrieved from: https://www.texasgop.org/wp-content/uploads/2016/01/PERM-PLATFORM.pdf.

${ }^{9}$ It doesn't even solve teachers' difficulty when trying to decide, for instance, how to teach students about Donald Trump's plan to build a border wall or explain the political and demographic dynamics that have led "Build the Wall!" to become a rallying cry among his supporters. Is it inappropriately partisan, for example, for a teacher to describe his plan as xenophobic race-baiting - and on the other hand would it be inappropriately partisan to deny it?
} 